\title{
Potential effects of vinasse as a soil amendment to control runoff and soil loss
}

\author{
Z. Hazbavi and S. H. R. Sadeghi \\ Department of Watershed Management Engineering, Faculty of Natural Resources, \\ Tarbiat Modares University, Noor, Iran \\ Correspondence to: S. H. R. Sadeghi (sadeghi@modares.ac.ir) \\ Received: 21 June 2015 - Published in SOIL Discuss.: 9 July 2015 \\ Revised: 9 January 2016 - Accepted: 15 January 2016 - Published: 17 February 2016
}

\begin{abstract}
Application of organic materials are well known as environmental practices in soil restoration, preserving soil organic matter and recovering degraded soils of arid and semiarid lands. Therefore, the present research focused on evaluating the effectiveness of vinasse, a byproduct mainly of the sugar-ethanol industry, on soil conservation under simulated rainfall. Vinasse can be recycled as a soil amendment due to its organic matter content. Accordingly, the laboratory experiments were conducted by using $0.25 \mathrm{~m}^{2}$ experimental plots at $20 \%$ slope and rainfall intensity of $72 \mathrm{~mm} \mathrm{~h}^{-1}$ with $0.5 \mathrm{~h}$ duration. The effect of vinasse was investigated on runoff and soil loss control. Experiments were set up as a control (with no amendment) and three treated plots with doses of $0.5,1$, and $1.5 \mathrm{~L} \mathrm{~m}^{-2}$ of vinasse subjected to simulated rainfall. Laboratory results indicated that vinasse at different levels could not significantly $(P>0.05)$ decrease the runoff amount and soil loss rate in the study plots compared to untreated plots. The average amounts of minimum runoff volume and soil loss were about $3985 \mathrm{~mL}$ and $46 \mathrm{~g}$ for the study plot at a $1 \mathrm{~L} \mathrm{~m}^{-2}$ level of vinasse application.
\end{abstract}

\section{Introduction}

Soil erosion is an environmental concern resulting in increased sedimentation, turbidity, and levels of pollutants in adjacent water bodies (Ebisemiju, 1990; Pieri et al., 2007; Girmay et al., 2009; Bhattarai et al., 2011; Bakr et al., 2012). According to the Forest, Rangeland and Watershed Management Organization of Iran, about USD 150 million is annually spent on the watershed management projects implemented to prevent or alleviate soil-erosion-related problems in the country (Sadeghi et al., 2011). This led to erosion control technologies receiving a great deal of attention to reduce soil erosion. Accordingly, soil erosion control has principal importance in soil management and conservation in developing countries like Iran (Newson, 2002; Haghjou et al., 2014). Besides that, soil management is important to crop productivity, environmental sustainability, and consequently human welfare.

Covering the bare soil with an appropriate material is one of the soil management practices that increases water infiltration and surface storage by enhancing the soil structure and porosity. The layer of residues protects the soil against erosion, inhibits weed germination, improves water retention, ameliorates physical and biological soil properties, and is a source of plant nutrients (Sheoran et al., 2010; Araujo-Junior et al., 2013; Prado et al., 2013). In addition, industrial processing of sugarcane to produce sugar and alcohol also generates residues, such as filter cake and vinasse, which have a great potential for use in agriculture as soil improvers and fertilizers (Prado et al., 2013). Meanwhile, to prevent soil loss many organic soil improvers are used (Tejada et al., 2009; Rigane and Medhioub, 2011). Additionally, according to Tejada et al. (2006a, b), the general increase of biomass $C$ in a soil can be associated with the constructive impact of organic materials on soil physical properties. The application of animal, industrial, and municipal wastes is also prevalent throughout the world as they can be an excellent source of nutrients and organic matter (Bhattarai et al., 2011). Several studies have evaluated the effects of composted organic wastes such as animal manure and sewage sludge compost on soil properties, quality, and productivity, dissolved or- 
ganic carbon and nitrate leaching (e.g., Adler and Sikora, 2005; Margesin et al., 2006; Bastida et al., 2007; Karami et al., 2012; Zornoza et al., 2013; Eykelbosh et al., 2015), but there are relatively few studies (e.g., Tejada and Gonzalez, 2006b, 2008; Tejada et al., 2007; Gholami et al., 2013; Sadeghi et al., 2015a, b; Cerdà et al., 2016; Prosdocimi et al., 2016) that evaluate the effect of organic waste and residues on runoff and soil loss control.

Application of organic amendment and mulches has already been proven as a method of improving soil physical properties leading to affect runoff and soil erosion (Albaladejo et al., 2000; Cerdà and Doerr, 2008). Moreover, organic amendments are increasingly being examined for their potential use in preventing soil losses (Tejada and Gonzalez, 2008). There are a variety of organic amendments for soil management and conservation, with different performance and mechanisms. In spite of that, different organic amendments - viz. cotton gin crushed compost and poultry manure, beet vinasse, sewage sludge, organic urban solid refuse, sheep manure, cow manure, rice husk, finely chopped reeds, wheat straw, and licorice (root) dregs (Agassi et al., 1998; Albaladejo et al., 2000; Ojeda et al., 2003; Tejada and Gonzalez, 2006b, 2008; Tejada et al., 2007; Nicolás et al., 2012; Karami et al., 2012) - have commonly been used for soil conservation in agricultural and forestry soils.

Recently, with advances in the industrial sector, significant amounts of wastes can be produced, which create another source of load on the environment. Also, the high cost of fertilizers and concerns about environmental protection have been great incentives to study recycling of the large quantities of organic residues produced as byproducts of the sugar and alcohol agro-industries in agriculture (Prado et al., 2013). For instance, the production of $1 \mathrm{~L}$ of ethanol generates on average between 10 and $15 \mathrm{~L}$ of vinasse. Vinasse is classified as a class II residue, not inert but not dangerous (Rocha et al., 2009). Vinasse, like other organic fertilizers, has high organic matter, $\mathrm{N}$, and $\mathrm{K}$ contents (Madejón et al., 2001), which promotes nutrient recycling in ecosystems, and causes less environmental impacts during production. It is an important byproduct of the ethanol and sugarcane industries and is intensively applied to soils in Brazil as liquid fertilizer (Ribeiro et al., 2013). However, the direct application of vinasse is constrained by its high salinity and high density of organic matter and other chemical materials. These issues can be mitigated through mixing the vinasse with other solid wastes. The environmental damage caused by discarding vinasse into the soil or running waters was an incentive to studies aiming to find alternative, economic applications for this residue. Results from such studies indicate that vinasse contributes to improvements in soil quality and agricultural productivity, if properly used (Prado et al., 2013).

Many studies have been performed to identify the effects of vinasse application on growth, development, and production of sugarcane and the physical properties of soil (e.g.,
Tejada et al., 2009; Jiang et al., 2010; Prado et al., 2013; Ribeiro et al., 2013), but very few studies have investigated the effects of application of vinasse on surface runoff and water soil loss rate. According to previous studies (Tejada and Gonzalez, 2006a, 2007; Tejada et al., 2006a, 2007), the application of beet vinasse had unfavorable impacts on some soil properties, viz. structural stability, bulk density, exchangeable sodium, microbial biomass, respiration, and enzymatic activities. Nonetheless, Espanã-Gamboa et al. (2011) showed that vinasse could be safely used in agriculture without contaminating soil, underground water, or crops, for energy recovery and animal feeding, if adequately managed.

A review of the literature demonstrated the effectiveness of different organic amendments on growth, development, and production of sugarcane and soil physical properties of soil as well. However, there was no comprehensive study on evaluation of the effect of vinasse amendment on runoff and soil loss control. In recent years, soil erosion has been extensively studied in the laboratory using rainfall simulators. Soil erosion plots and rainfall simulators are two important research equipments employed in erosion studies worldwide. They allow the production of runoff and soil loss under repeatable and controlled conditions. In addition, the employment of different sized plots is practically applicable, logically economic, and easily controllable and repeatable due to which their further utilizations have been advised with particular considerations (Sadeghi et al., 2012). Research on vinasse is in its infancy and as such substantially more data are required before robust predictions can be made regarding the effects of vinasse application to soils, across a range of soil, climatic, and land management factors. The present study therefore examines the potential role of vinasse amendment on runoff and soil loss reduction on a silt loam soil collected from a summer rangeland in northeastern Iran using a simulated rainfall intensity of $72 \mathrm{~mm} \mathrm{~h}^{-1}$ and slope of $20 \%$.

\section{Materials and methods}

\subsection{Soil properties}

The soil required for the study was provided from the soil surface layer $(0-30 \mathrm{~cm})$ from the Badranlou area $\left(57^{\circ} 11^{\prime} \mathrm{E}\right.$ and $37^{\circ} 29^{\prime} \mathrm{N}$ ) in North Khorasan Province, Iran, and transported to the laboratory. The area is mainly under a dry land farming system and very prone to soil erosion. The area belongs to the cold substeppic of the Irano-Turanian zone (slight Mediterranean affinities). The average annual precipitation and average annual temperature of Badranlou is $247 \mathrm{~mm}$ and $14{ }^{\circ} \mathrm{C}$, respectively. The soil used was classified as a Regosol (IUSS Working Group, 2016).

The collected soil was air-dried, passed through a $2 \mathrm{~mm}$ sieve, and analyzed for various physicochemical properties. Soil texture was determined using the hydrometer method according to Bouyoucos (1962). Soil organic matter (SOM) was obtained by multiplying total soil organic carbon by 
Table 1. Main original soil characteristics $(n=3)$.

\begin{tabular}{ll}
\hline Soil property & Description \\
\hline Soil texture & silty loam (48\% silt, $28 \%$ clay, and $24 \%$ sand $)$ \\
Organic matter $(\%)$ & 0.155 \\
$\mathrm{pH}$ & 8.2 \\
Electrical conductivity $\left(\mu \mathrm{S} \mathrm{m}^{-1}\right)$ & 137.3 \\
Bulk density $\left(\mathrm{g} \mathrm{cm}^{-3}\right)$ & 1.3 \\
\hline
\end{tabular}

1.724. Total soil organic carbon was measured by the Walkley and Black wet dichromate oxidation method (Nelson and Somers, 1982). The $\mathrm{pH}$ and electrical conductivity (EC) were determined in a $1: 2$ soil: water suspension by $\mathrm{pH}$ and $\mathrm{EC}$ meters (Hati et al., 2007). Bulk density at air-dried moisture content was measured by Plaster (1985) method (clod method). Properties of the study surface soil $(0-30 \mathrm{~cm})$ are shown in Table 1.

\subsection{Plot preparation}

Experimental plots with dimensions of $0.5 \mathrm{~m}$ long, $0.5 \mathrm{~m}$ wide, and $0.3 \mathrm{~m}$ deep were used for the present study. The soil was then prepared for application and simulated in the plots using previously reported methods (Thompson and Beckmann, 1959; Loch and Donnollan, 1988; Kukal and Sarkar, 2011). The upper $10 \mathrm{~cm}$ of the soil was compacted by concrete roller to achieve the desired bulk density of $1.3 \mathrm{~g} \mathrm{~cm}^{-3}$ and similar to the field conditions. To establish the filter layer under the experimental soils, three layers of mineral pumice grains with different sizes with total thickness of $17 \mathrm{~cm}$ were packed. Based on the annual average soil moisture content reported for the soil in the study area, the soil was also treated to contain a moisture content of $35 \%$ (Behzadfar et al., 2012; Hazbavi et al., 2013). After soil compaction, the plots were established in water ponds for $12 \mathrm{~h}$. After the plots were extracted from the water ponds, the vinasse was spread over the soil surface (Hazbavi et al., 2013; Sadeghi et al., 2015a, b, 2016).

\subsection{Vinasse characteristics}

Vinasse used for the experiment was produced by Research and Training Institute for the Industrial Development of Sugarcane in Khuzestan Province, Iran. pH and EC of vinasse were determined by $\mathrm{pH}$ and EC meters. Organic matter was determined by the dry combustion method (MAPA, 1986). Calcium $(\mathrm{Ca})$, potassium $(\mathrm{K})$, and magnesium $(\mathrm{Mg})$ were determined by atomic absorption spectrometer after nitric and perchloric acid digestion. Chemical oxygen demand (COD) was determined by the closed reflux, colorometric method (APHA, 1998). The general properties of the vinasse have been summarized in Table 2 .

The levels of vinasse application $\left(0.5,1\right.$, and $\left.1.5 \mathrm{Lm}^{-2}\right)$ were selected based on existing information application of
Table 2. Chemical characteristics of vinasse applied in the study.

\begin{tabular}{ll}
\hline Property & Description \\
\hline $\mathrm{pH}$ & 5 \\
Electrical conductivity $\left(\mu \mathrm{S} \mathrm{cm}^{-1}\right)$ & 1657 \\
Organic matter $\left(\mathrm{g} \mathrm{kg}^{-1}\right)$ & 100 \\
$\mathrm{Bulk} \mathrm{density}\left(\mathrm{g} \mathrm{cm}^{-3}\right)$ & 1.11 \\
$\mathrm{Ca}\left(\mathrm{mg} \mathrm{kg}^{-1}\right)$ & 137.0 \\
$\mathrm{Mg}\left(\mathrm{mg} \mathrm{kg}^{-1}\right)$ & 154.4 \\
Chemical oxygen demand $\left(\mathrm{g} \mathrm{kg}^{-1}\right)$ & 91.4 \\
Moisture content $(\%)$ & 93 \\
\hline
\end{tabular}

vinasse for other purposes and other amendments, avoiding considerable environmental pollution due to high contents of $\mathrm{N}$ and $\mathrm{K}$ probably leading to high salinity and high density as well as feasibility of application and accessibility (Madejón et al., 2001; Tejada and Gonzalez, 2005, 2006a, b; Tejada et al., 2007, 2009; Jiang et al. 2010; Espanã-Gamboa et al., 2011). Three levels of $0.5,1$, and $1.5 \mathrm{Lm}^{-2}$ of vinasse were sprayed on the soil surface in three replications by a small manual pump and left for $24 \mathrm{~h}$ to increase the stability of the vinasse layer on the soil surface and mimic the natural conditions. To conduct the comprehensive comparison, one control treatment (without vinasse) at three replications was also applied. Urban tap water was used for the control treatment and the experimental setup was similar to that used for other vinasse treatments (Sadeghi et al., 2016).

\subsection{Laboratory experiments}

To evaluate the effectiveness of vinasse for runoff and soil loss control, laboratory experiments were conducted under a rainfall simulator at the Rainfall and Soil Erosion Simulation Laboratory of Faculty of Natural Resources of Tarbiat Modares University, located in Noor Campus, Mazandaran Province, Iran. The rainfall simulator consists of a $4000 \mathrm{~L}$ water tank and 27 precalibrated nozzles in three parallel lines designed to simulate raindrops of $1.3 \mathrm{~mm}$ average size. The drops fall from a height between 4 and $6 \mathrm{~m}$ at the upper and lower parts of the plot, respectively, reaching a speed of $7 \mathrm{~m} \mathrm{~s}^{-1}$ (Gholami et al., 2013; Sadeghi et al., 2015a, b). The laboratory experiments were conducted at $20 \%$ slopes under simulated rainfall intensity of $72 \mathrm{~mm} \mathrm{~h}^{-1}$ with duration 
of $30 \mathrm{~min}$. The rainfall intensity of $72 \mathrm{~mm} \mathrm{~h}^{-1}$ with duration of 30 min was considered representative of the climatological condition of the origin of the soil, obtained through intensityduration-frequency (IDF) curves analysis for data collected from the nearest synoptic station (Bojnourd, North Khorasan Province in the northeast of Iran) with the return period of 50 years. The slope of $20 \%$ was selected based on the average slope of the original area where the soil was collected (Hazbavi, 2013; Hazbavi et al., 2013; Sadeghi et al., 2014). A general view of the experimental setup is shown in Fig. 1.

For each event, the time to runoff initiation was recorded as the elapsed time between the start of rainfall and the time at which surface runoff began entering the runoff collection container located at the end of the plot. Runoff was sampled at different time steps of $2-5 \mathrm{~min}$ and its volume was accordingly measured. The collection gutter at the lower end of each box was protected by a shield to prevent rainfall from directly entering the collection container. The amount of soil loss was then measured using a decantation procedure: oven drying at $105^{\circ} \mathrm{C}$ for $24 \mathrm{~h}$ and weighing by means of a high-precision scale (Gholami et al., 2013; Sadeghi et al., 2016). The runoff commencement and cessation times were also recorded. The time of runoff commencement and cessation times and regular measurement of runoff volume were measured by a chronometer and standard gauged cylinders, respectively (Gholami et al., 2013; Sadeghi et al., 2014, 2015a, b).

\subsection{Statistical analyses}

All analyses were performed on triplicate samples and subjected to analysis of variance (ANOVA). The data were tested for homogeneity of variances at a significance level of $P<0.05$ and probability values of less than 0.05 were then considered statistically significant in one-way ANOVA. Significant means were subjected to analysis by Duncan's multiple range test $(P<0.05)$. The SPSS V.19 software package was used for the statistical analyses.

\section{Results and discussion}

\subsection{Runoff}

The variations in runoff volume with rainfall duration for various vinasse application rates are shown in Fig. 2 and Table 3.

The average maximum and minimum runoff volumes were 18547 and $15940 \mathrm{~mL} \mathrm{~m}^{-2}$ at 1.5 and $1 \mathrm{Lm}^{-2}$ level of vinasse treated plots, respectively (Table 3 ). The ANOVA results showed that the effect of vinasse on runoff volume was not significant, which is consistent with Madejón et al. (2001), who reported that a single application of vinasse did not significantly influence runoff and erosion from simulated rainfall. Increased runoff in $1.5 \mathrm{~L} \mathrm{~m}^{-2}$ vinasse-treated plots in comparison with the other treatments (although not significant) may suggest changing effectiveness of vinasse on

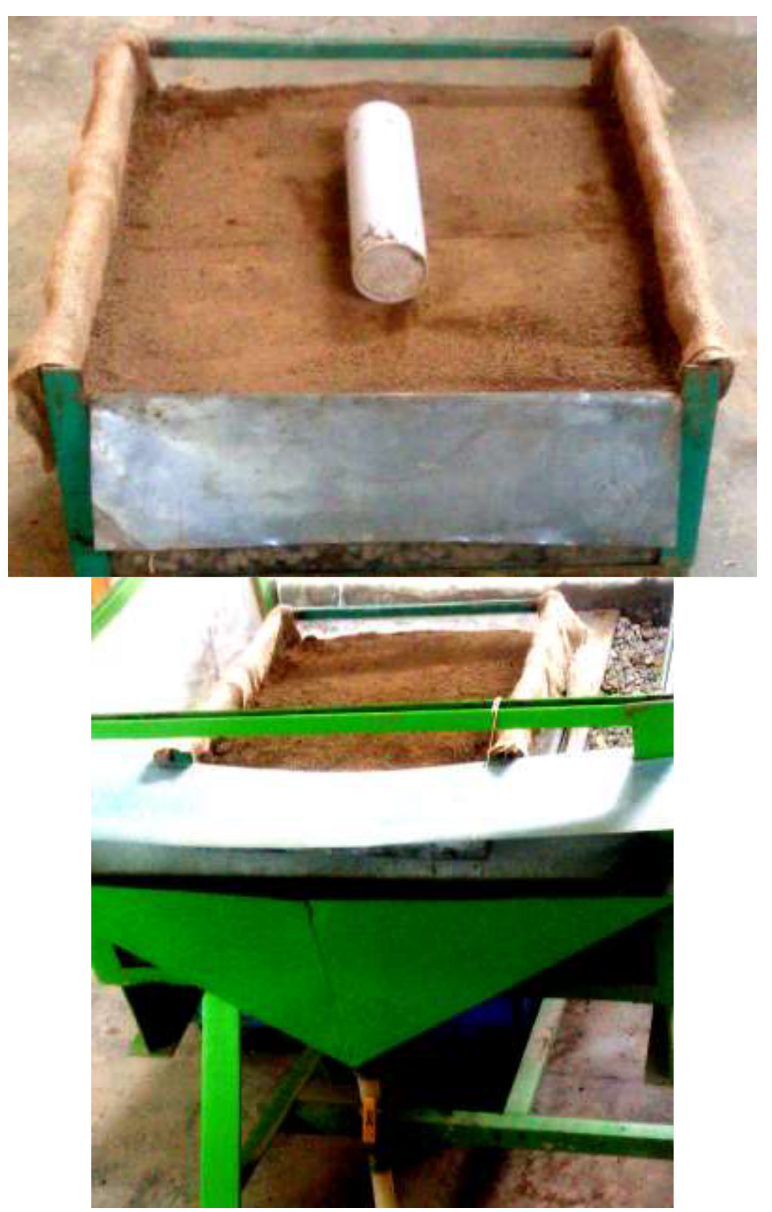

Figure 1. A general view of the experimental setup at the Rainfall and Soil Erosion Simulation Laboratory of Tarbiat Modares University, Iran.

runoff control. It may be due to water repellency phenomena. Based on laboratory observations, it is hypothesized that the increase in usage of vinasse may affect water repellency and has the potential to be easily transported in surface runoff at high levels. Agassi et al. (1998) verified that the hydrophobic sound effects, which are common to a range of organic amendments, may decrease the infiltration rate in soil treated with sludge as an organic amendment.

The runoff commencement and cessation times under different vinasse treatments are shown in Fig. 3. The runoff commencement time was recorded at the onset of when runoff reached the plot outlet. The addition of $1.5 \mathrm{~L} \mathrm{~m}^{-2}$ of vinasse delayed the runoff commencement up to $3.42 \mathrm{~min}$, compared to the control treatment with a commencement time of $1.53 \mathrm{~min}$. These results agree with previous studies (e.g., Gholami et al., 2013; Sadeghi et al., 2015a) showing that some organic amendments delay runoff commencement time and delaying runoff means more water infiltration. The addition of $1.5 \mathrm{~L} \mathrm{~m}^{-2}$ of vinasse showed a runoff cessation time of $1895 \mathrm{~s}$, which was delayed compared to the con- 


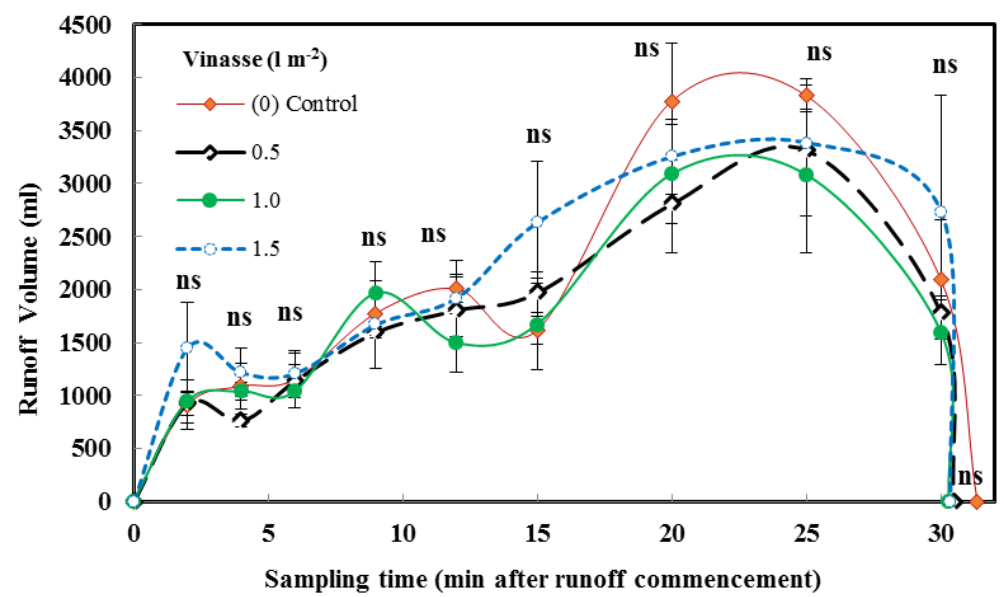

Figure 2. Variations of runoff volume per $\mathrm{m}^{2}$ area under different vinasse treatments under study conditions (rainfall intensity of $72 \mathrm{~mm} \mathrm{~h}^{-1}$ and experiment duration of $30 \mathrm{~min})$; "ns" indicates non significant differences among study treatments $(P>0.05)$ for each sampling time.

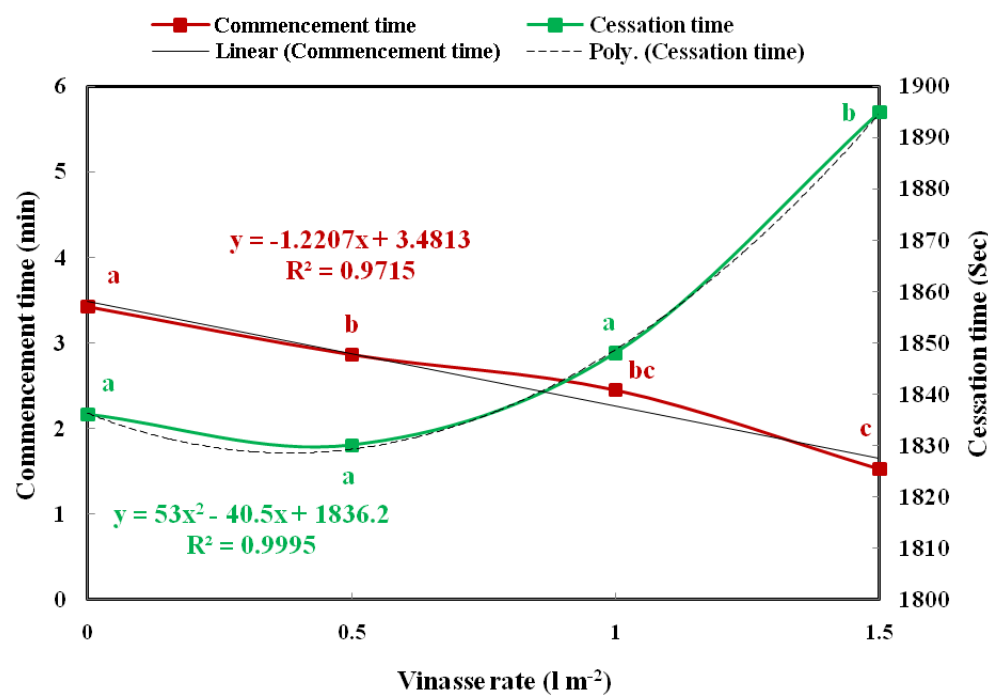

Figure 3. Runoff commencement and cessation times variation under different vinasse treatments and under study conditions $\left(0.25 \mathrm{~m}^{-2}\right.$ small plot, rainfall intensity of $72 \mathrm{~mm} \mathrm{~h}^{-1}$ and experiment duration of $30 \mathrm{~min}$ ); different letters indicate significant differences among study treatments $(P<0.05)$ for each sampling time.

trol treatment (1836s). The lack of significant differences among treatments confirmed that the vinasse addition as a soil amendment did not significantly affect runoff. Saturation of pores may be a reason behind this finding, since vinasse partly fills up the pores in soil, and partly remains on the soil surface.

\subsection{Soil loss}

Table 4 contains the specific values of average soil loss for vinasse treatments. The average values of eroded soil under different vinasse treatments under experiment conditions are shown in Fig. 4. There was a trend showing decreased soil loss with vinasse addition, but owing to the high variability, differences were not significant $(P>0.05)$, which agrees with Madejón et al. (2001). Tejada and Gonzalez (2005) showed that an increase in electrical conductivity caused by high vinasse application rate adversely affects soil total porosity, bulk density, and structural stability. Thus, soil physical properties can be influenced by vinasse application under different conditions from those considered in the present study such as different timescales and soil types. These changes in soil properties can have a substantial impact on runoff and soil loss from fields where vinasse has been applied. Tejada et al. (2006a) found that organic amendments improve soil structure because they promote the flocculation of clay minerals, which is important for soil particle aggregation. 
Table 3. Mean and standard deviation (Mean $\pm \mathrm{SD}$ ) of runoff volume $(\mathrm{mL})$ under different vinasse treatments in the study $0.25 \mathrm{~m}^{2}$ plots.

\begin{tabular}{lcccc}
\hline Vinasse rate $\left(\mathrm{Lm}^{-2}\right)$ & 0 (Control) & 0.5 & 1.0 & 1.5 \\
\hline Mean \pm SD & $18250 \pm 3163$ & $16105 \pm 3066$ & $15940 \pm 4102$ & $18548 \pm 1710$ \\
$F$ value & & \multicolumn{2}{c}{$0.583 \mathrm{~ns}$} \\
\hline
\end{tabular}

"ns" indicates non-significant differences among study treatments $(P>0.05)$.

Table 4. Mean and standard deviation (Mean $\pm \mathrm{SD}$ ) of soil loss amount $(\mathrm{g})$ under different vinasse treatments in the study $0.25 \mathrm{~m}^{2}$-plots.

\begin{tabular}{lcccc}
\hline Vinasse rate $\left(\mathrm{Lm}^{-2}\right)$ & 0 (Control) & 0.5 & 1.0 & 1.5 \\
\hline Mean $\pm \mathrm{SD}$ & $276.1 \pm 47.4$ & $234.5 \pm 120.6$ & $182.6 \pm 51.2$ & $212.3 \pm 50.3$ \\
$F$ value & \multicolumn{4}{c}{$0.848 \mathrm{~ns}$} \\
\hline
\end{tabular}

"ns" indicates non-significant differences among study treatments $(P>0.05)$.

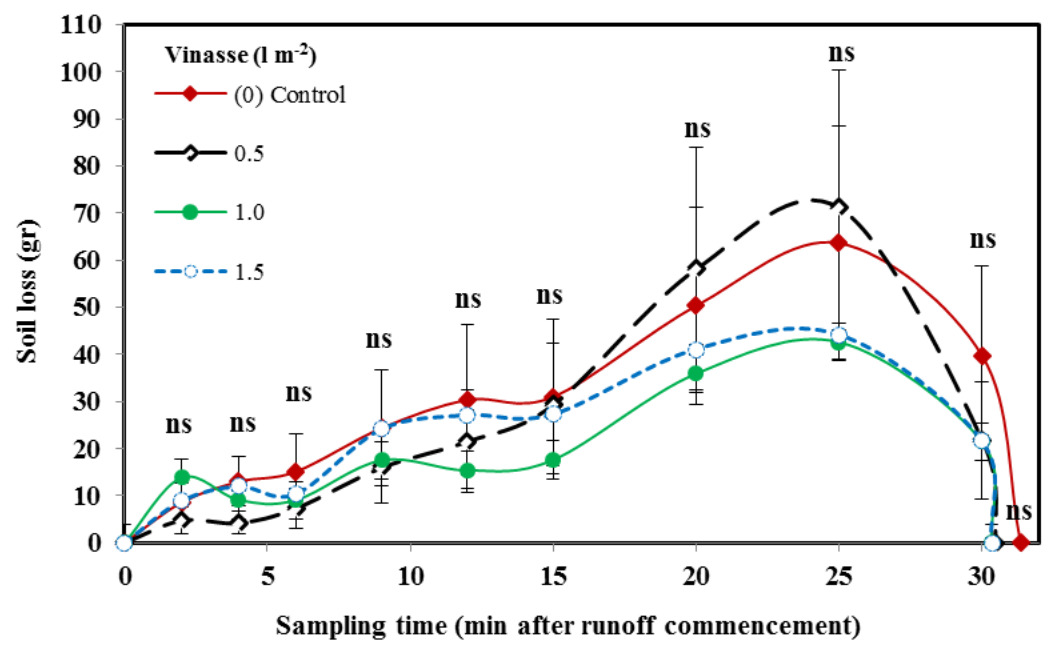

Figure 4. Variations of soil loss per $\mathrm{m}^{2}$ area under different vinasse treatments under study conditions (rainfall intensity of $72 \mathrm{~mm} \mathrm{~h}^{-1}$ and experiment duration of $30 \mathrm{~min})$; "ns" indicates non significant differences among study treatments $(P>0.05)$ for each sampling time.

Tejada et al. (2009) reported, in particular, that the fresh beet vinasse application had a negative effect on the soil physical, chemical, and biological properties. They stated that the fresh beet vinasse increased soil loss and decreased plant cover because of high quantities of monovalent cations such as $\mathrm{Na}^{+}$. In soils amended with beet vinasse a degradation of soil structure and an increase in erosion were observed due to the enrichment of the cation exchange capacity by monovalent cations, such as $\mathrm{K}$ (Tejada and Gonzalez, 2006a; Tejada et al., 2007). High saturation of K on the cation exchange sites may lead to soil dispersion and, consequently, to soil erosion and land degradation. In addition, whenever vinasse is applied to silty loam soil, a part of it fills the voids of soil, and other parts stay on the soil aggregates surface. The effects of vinasse may be temporary, since the organic compounds in vinasse are highly degradable from vinasse cementing the microaggregates and favoring the flocculation of clay fraction (Ribeiro et al., 2013).

\section{Conclusions}

The results of the study indicated that the single application of vinasse alone did not significantly influence runoff and erosion. Vinasse composts or mixed with other amendments should be also tested to reduce soil erosion and water loss. Since the runoff and soil loss ratios from different plots and under other environmental conditions may be different from those obtained in the present study, further research is needed for better understanding of the potential benefits and limitations of various applications of vinasse for sound management of water and soil and to allow the drawing comprehensive conclusions. More and longer-term experiments are also needed for monitoring and evaluating long-term effects of vinasse on soil hydrology and erosion processes with particular focus on environmental effects. 
Acknowledgements. The authors are thankful to Hassan Hamdi, the managing director of the Research and Training Institute for the Industrial Development of Sugarcane in Khuzestan Province, Iran, for providing the vinasse amendment.

Edited by: R. Zornoza

\section{References}

Adler, P. R. and Sikora, L. J.: Mesophilic composting of arctic char manure, Compost Sci Util., 13, 34-42, 2005.

Agassi, M., Kirsten, W. F. A., Loock, A. H., and Fine, P.: Percolation and leachate composition in a disturbed soil layer mulched with sewage biosolids, Soil Till. Res., 45, 359-372, 1998.

Albaladejo, J., Castillo, V., and Diaz, E.: Soil loss and runoff on semiarid land as amended with urban solid refuse, Land Degrad. Dev., 11, 363-373, 2000.

APHA: Standard method for the examination of water and wastewater, American Public Health Association, 541 pp., available at: http://www.mwa.co.th/download/file_upload/SMWW_ 1000-3000.pdf, last access: 17 January 2016, 1998.

Araujo-Junior, C. F., Noedi Rodrigues, B., Dias Chaves, J. C., and Yada Junior, G. M.: Soil physical quality and carbon stocks related to weed control and cover crops in a Brazilian Oxisol, Chapter 8, in: Weed and Pest Control - Conventional and New Challenges, edited by: Soloneski, S., InTech, doi:10.5772/54363, 181-205, 2013.

Bakr, N., Weindorf, D. C., Zhu, Y., Arceneaux, A. E., and Selim, H. M.: Evaluation of compost/mulch as highway embankment erosion control in Louisiana at the plot-scale, J. Hydrol., 468469, 257-267, 2012.

Bastida, F., Moreno, J. L., García, C., and Hernández, T.: Addition of urban waste to semiarid degraded soil: long-term effect, Pedosphere, 17, 557-567, 2007.

Behzadfar, M., Sadeghi, S. H. R., Khangani, M. J., and Hazbavi, Z.: Effectability of runoff and sediment yield from soils induced by freezing and thawing cycle under simulated rainfall condition, Soil and Water Resources Conservation, 2, 13-25, 2012 (in Persian with English abstract).

Bhattarai, R., Kalita, P. K., Yatsu, Sh., Howard, H. R., and Svendsen, N. G.: Evaluation of compost blankets for erosion control from disturbed lands, J. Environ. Manag., 92, 803-812, 2011.

Bouyoucos, G. J.: Hydrometer method improved for making particle size analysis of soils, Agron. J., 54, 464-465, 1962.

Cerdà, A. and Doerr, S. H.: The effect of ash and needle cover on surface runoff and erosion in the immediate post-fire period, Catena, 74, 256-263, 2008.

Cerdà, A., González-Pelayo, Ó., Gimeìnez-Morera, A., Jordaìn, A., Pereira, P., Novara, A., Brevik, E. C., Prosdocimi, M., Mahmoodabadi, M., Keesstra, S., García Orenes, F., and Ritsema, C.: The use of barley straw residues to avoid high erosion and runoff rates on persimmon plantations in Eastern Spain under low frequency - high magnitude simulated rainfall events, Soil Res., available at: http://www.publish.csiro.au/SR15092, last access: 17 January 2016.

Ebisemiju, F. S.: Sediment delivery ratio prediction equations for short catchment slopes in a humid tropical environment, J. Hydrol., 114, 191-208, 1990.
Espanã-Gamboa, E., Mijangos-Cortes, J., Barahona-Perez, L., Dominguez-Maldonado, J., Hernández-Zarate, G., and AlzateGaviria, L.: Vinasses: characterization and treatments, Waste Manange. Res., 29, 1235-1250, 2011.

Eykelbosh, A. J., Johnson, M. S., and Couto, E. G.: Biochar decreases dissolved organic carbon but not nitrate leaching in relation to vinasse application in a Brazilian sugarcane soil, J. Environ. Manage., 149, 9-16, 2015.

Haghjou, M., Hayati, B., and Momeni Choleki, D.: Identification of factors affecting adoption of soil conservation practices by some rainfed farmers in Iran, J. Agric. Sci. Technol., 16, 957967, 2014.

Hati, K. M., Biswas, A. K., Bandyopadhyay, K. K., and Misra, A. K.: Soil properties and crop yields on a vertisol in India with application of distillery effluent, Soil Till. Res., 92, 60-68, 2007.

Hazbavi, Z.: Soil erosion control by application of polyacrylamide to minimize its residues in runoff and sediment, MSc thesis, Iran, Tarbiat Modares University, 98 pp., 2013.

Hazbavi, Z., Sadeghi, S. H. R., and Younesi, H.: Analysis and assessing effectability of runoff components from different levels of polyacrylamide, Water Soil Resour. Conserv. J., 2, 1-13, 2013.

Gholami, L., Sadeghi, S. H. R., and Homaee, M.: Straw mulching effect on splash erosion, runoff and sediment yield from eroded plots, Soil Sci. Soc. Am. J., 77, 268-278, 2013.

Girmay, G., Singh, B. R., Nyssen, J., and Borrosen, T.: Runoff and sediment associated nutrient losses under different land uses in Tigray, Northern Ethiopia, J. Hydrol., 376, 70-80, 2009.

IUSS Working Group: The World Reference Base (WRB), International Union of Soil Sciences, available at: http://www.fao.org/soils-portal/soil-survey/soil-classification/ world-reference-base/en/, last access: 17 January 2016.

Jiang, Z. P., Wei, G. P., Liao, Q., Su, T. M., Meng, Y. C., Zhang, H. Y., Lu, C. Y., and Li, Y. R.: Effect of long-term vinasse application on physical properties of soil in sugarcane fields, Sugar Tech., 41, 795-799, 2010.

Karami, A., Homaee, M., Afzaliniab, S., Ruhipour, H., and Basirat, S.: Organic resource management: impacts on soil aggregate stability and other soil physico-chemical properties, Agr. Ecosyst Environ., 148, 2-28, 2012.

Kukal, S. S. and Srakar, M.: Laboratory simulation studies on splash erosion and crusting in relation to surface roughness and raindrop size, J. Indian Soc. Soil Sci., 59, 87-93, 2011.

Loch, R. J. and Donnollan, T. E.: Effects of the amount of stubble mulch and overland flow on erosion of a cracking clay soil under simulated rain, Aust. J. Soil. Res., 26, 661-672, 1988.

Madejón, L., López, R., Murillo, J. M., and Cabrera, F.: Agricultural use of three (sugar-beet) vinasse composts: effect on crops and chemical properties of a cambisol soil in the Guadalquivir river valley (SW Spain), Agr. Ecosyst Environ., 84, 55-65, 2001.

MAPA: Métodos oficiales de análisis, Ministerio de Agricultura (Ed.), Pescay Alimentación, 1, 221-285, 1986.

Margesin, R., Cimadom, J., and Schinner, F.: Biological activity during composting of sewage sludge at low temperature, Int. Biodeter. Biodegr., 57, 88-92, 2006.

Newson, M.: Land, water, and development: sustainable management of river basin systems, Taylor \& Francis e-Library, 460 pp., 2002.

Nelson, D. W. and Somers, L. E.: Total carbon, organic carbon and organic matter, in: Methods of Soil Analysis, Part 2, edited by: 
Page, A. L., Agronomy No. 9, Monograph Series, American Society of Agronomy, Madison, WI, 539-579, 1982.

Nicolás, C., Masciandaro, G., Hernández, T., and Garcia, C.: Chemical-structural changes of organic matter in a semi-arid soil after organic amendment, Pedosphere, 22, 283-293, 2012.

Ojeda, G., Alcaniz, J. M., and Ortiz, O.: Runoff and losses by erosion in soils amended with sewage sludge, Land Degrad. Dev., 14, 563-573, 2003.

Pieri, L., Bittelli, M., Wu, J. Q., Dun, Sh., Flanagan, D. C., Pisa, P. R., Ventura, F., and Salvatorelli, F.: Using the water erosion prediction project (WEPP) model to simulate field-observed runoff and erosion in the Apennines Mountain Range, Italy, J. Hydrol., 336, 84-97, 2007.

Plaster, E. J.: Soil science and management, Delmar Publishers Inc., Albany, NY, 124 pp., 1985.

Prado, R. de M., Caione, G., and Campos, C. N. S.: Filter Cake and Vinasse as Fertilizers Contributing to Conservation Agriculture, Appl. Environ. Soil Sci., 2013, 1-8, doi:10.1155/2013/581984, 2013.

Prosdocimi, M., Jordán, A., Tarolli, P., Keesstra, S., Novara, A., and Cerdà, A.: The immediate effectiveness of barley straw mulch in reducing soil erodibility and surface runoff generation in Mediterranean vineyards, Sci. Total Environ., 547, 15, 323330, 2016.

Ribeiro, B. T., Lima, J. M. D., Curi, N., and Oliveira, G. C. D.: Aggregate breakdown and dispersion of soil samples amended with sugarcane vinasse, Scientia Agricola, 70, 435-441, 2013.

Rigane, M. K. and Medhioub, K.: Assessment of properties of Tunisian agricultural waste composts: application as components in reconstituted anthropic soils and their effects on tomato yield and quality, Resour. Conserv. Recy., 55, 785-792, 2011.

Rocha, M. H., Lora, E., and Venturini, O. J.: Life Cycle Analysis of Different Alternatives for the Treatment and Disposal of Ethanol Vinasse, Zuckerindustrie, 133, 88-93, 2009.

Sadeghi, S. H. R., Moatamednia, M., and Behzadfar, M.: Spatial and Temporal Variations in the Rainfall Erosivity Factor in Iran, J. Agric. Sci. Tecnol., 13, 451-464, 2011.

Sadeghi, S. H. R., Moosavi, V., Karami, A., and Behnia, N.: Soil erosion assessment and prioritization of affecting factors at plot scale using the Taguchi method, J. Hydrol., 448-449, 174-180, 2012.

Sadeghi, S. H. R., Hazbavi, Z., and Younesi, H.: Sustainable watershed management through applying appropriate level of soil amendments, Sustainable Watershed Management - Proceedings of the 2nd International Conference on Sustainable Watershed Management, SUWAMA 2014, 13-15 October 2014, Sarigerme, Turkey, 183-185, 2014.
Sadeghi, S. H. R., Gholami, L., Homaee, M., and Khaledi Darvishan, A.: Reducing sediment concentration and soil loss using organic and inorganic amendments at plot scale, Solid Earth, 6, 445-455, doi:10.5194/se-6-445-2015, $2015 \mathrm{a}$.

Sadeghi, S. H. R., Gholami, L., Sharifi, E., Khaledi Darvishan, A., and Homaee, M.: Scale effect on runoff and soil loss control using rice straw mulch under laboratory conditions, Solid Earth, 6, 1-8, doi:10.5194/se-6-1-2015, 2015b.

Sheoran, V., Sheoran, A. S., and Poonia, P.: Soil reclamation of abandoned mine land by revegetation: A Review, Int. J. Soil Sediment Water, 3, 1-20, 2010.

Tejada, M. and Gonzalez, J. L.: Beet vinasse applied to wheat under dryland conditions affects soil properties and yield, Eur. J. Agron., 23, 336-347, 2005.

Tejada, M. and Gonzalez, J. L.: Effects of two beet vinasse forms on soil physical properties and soil loss, Catena, 68, 41-50, $2006 \mathrm{a}$.

Tejada, M. and Gonzalez, J. L.: The relationships between erodibility and erosion in a soil treated with two organic amendments, Soil Till. Res., 91, 186-198, 2006b.

Tejada, M. and Gonzalez, J. L.: Influence of organic amendments on soil structure and soil loss under simulated rain, Soil Till. Res., 93, 197-205, 2007.

Tejada, M. and Gonzalez, J. L.: Influence of two organic amendments on the soil physical properties, soil losses, sediments and runoff water quality, Geoderma, 145, 325-334, 2008.

Tejada, M., Garcia, C., Gonzalez, J. L., and Hernandez, M. T.: Organic amendment based on fresh and composted beet vinasse: influence on physical, chemical and biological properties and wheat yield, Soil Sci. Soc. Am. J., 70, 900-908, 2006 a.

Tejada, M., Hernandez, M. T., and Garcia, C.: Application of two organic amendments on soil restoration: effects on the soil biological properties, J. Environ. Qual., 35, 1010-1017, 2006 b.

Tejada, M., Moreno, J. L., Hernandez, M. T., and Garcia, C.: Application of two beet vinasse forms in soil restoration: effects on soil properties in an arid environment in southern Spain, Agr. Ecosyst. Environ., 119, 289-298, 2007.

Tejada, M., Garcia-Martinez, A. M., and Parrado, J.: Effects of a vermicompost composted with beet vinasse on soil properties, soil losses and soil restoration, Catena, 77, 238-247, 2009.

Thompson, C. H. and Beckmann, G. G.: Soils and land use in the Toowoomba area, darling downs, Queensland, CSIRO Australia, Soil land use series, 28, 78 pp., 1959.

Zornoza, R., Faz, A., Martínez-Martínez, S., Acosta, J. A., GómezLópez, M. D., and Avilés-Marín, S. M.: Marble waste and pig slurry increment soil quality and reduce metal availability in a tailing pond, Publicado en Terra Latinoamericana, 31, 105-114, 2013. 